RAD Conference Proceedings, vol. 4, pp. 173-178, 2020

ISSN 2466-4626 (online) | DOI: 10.21175/RadProc.2020.35

www.rad-proceedings.org

\title{
SULFONAMIDE LIGAND FRAMEWORKS FOR Sm(III) EXTRACTION FROM ALKALINE HIGH-LEVEL WASTE
}

\author{
Xinrui Zhang1, Oluwaseun W. Adedoyin', \\ Maria L. Masferrer Bertoli', Evgen V. Govor ${ }^{1,2}$, Konstantinos Kavallieratos ${ }^{1}$
}

${ }^{1}$ Department of Chemistry \& Biochemistry, Florida International University, Miami, Florida, United States ${ }^{2}$ Applied Research Center, Florida International University, Miami, Florida, United States

\begin{abstract}
As part of our efforts to develop efficient extractants for highly alkaline high-level waste at the Savannah River Site, extraction studies of Sm(III) by three types of sulfonamide ligands have been carried out. Aqueous phases of various alkalinity ( $\mathrm{pH} 10$ - 14) were used, while dichloromethane was the organic phase. Analysis of the aqueous phases by the Arsenazo-III UV-Vis spectrophotometric method was carried out following stripping of the organic phases with o.1 $\mathrm{M} \mathrm{HNO}_{3}$. The results indicate that all three types of sulfonamides exhibit strong Sm(III) extraction and recovery at $\mathrm{pH}$ range of 10-11.5 in the presence of an organic base (triethylamine). A UV-Vis titration study of disulfonamide (DSA-7) with Sm(III) is indicative of 1:1 M/L complexation in solution in accordance with our previously published work with analogous disulfonamides.
\end{abstract}

Key words: Alkaline high-level waste, sulfonamide; lanthanide; extraction; coordination

\section{INTRODUCTION}

The persistent problem of large volumes of alkaline high-level waste (HLW) at the Hanford Site (HS) and the Savannah River Site (SRS) as a result of weapons production during the cold war has generated interest in integrated separation treatment processes using solvent extraction with synthetic ligands.[1] There are two sequential processes currently applied at SRS for integrated processing: 1) The well-developed Next-Generation Caustic Side Solvent Extraction (NG-CSSX) process, invented at Oak Ridge National Laboratory, has addressed Cesium separation at Savannah River successfully, by using calixarene ligands;[2] 2) The sorption-based Actinide Removal Process (ARP) used for separation of Strontium and Actinides using monosodium titanate. [3] This latter process, even though successful is much slower than solvent extraction, and thus presents the kinetic bottleneck for integrated tank treatment and closure. Furthermore, for some tanks with high actinide content, multiple strikes are needed. In this work we aim to develop compatible organic actinide extractants, which can be used directly in the CSSX solvent for an overall simpler and more economic extraction-based HLW treatment that could -at minimum- reduce the amount of titanate and extensive contact times with the sorbent during ARP, and -at best- greatly simplify integrated processing, by eliminating the need for a sorption step all together.

For successful extraction from the alkaline medium, special consideration must be given to the ligand design, with emphasis on ligands that can provide suitable binding sites [4] taking into account that Ln(III) and An(III) prefer to complex with electron-rich $-\mathrm{O}$ and $-\mathrm{N}$ sites. Another consideration is the ability to form soluble complexes under the prevailing alkaline conditions. In the literature, various ligand derivatives, such as alkyl(aminomethyl) phenols,[5] calix[4]arenes,[6-7] thiacalix,[8] and alkylpyrocathecols,[9-10] have been applied for the extraction of f-elements from high $\mathrm{pH}$, with alkylpyrocathecols showing Am[III] extraction as high as $97 \%$ from $6 \mathrm{M} \mathrm{NaOH}$. [10]

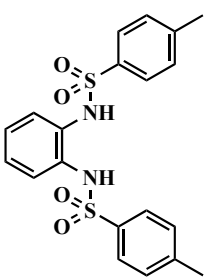

DSA-1

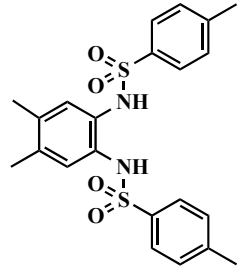

DSA-3
Figure 1. Structures of DSA-1 and DSA-3

Several sulfonamide-based ligands have been synthesized by our group aiming at f-element extraction from alkaline solutions, and have yielded promising results for Sm(III) extraction, which was used as a surrogate for Am(III). Our group has reported that a tripodal trisulfonamide ligand, 2,4,6-tris-(4-(iso-propyl)-phenylsulfamoylmethyl)benz ene gave $52 \% \mathrm{Sm}$ (III) recovery from $2 \times 10^{-4} \mathrm{M} \mathrm{NaOH}$ in the presence of $0.1 \mathrm{M} \mathrm{NaNO}_{3}$.[11] More recently, Sm(III) extraction from alkaline media by simpler diarylsulfonamide derived ligands (Figure 1) gave even better results with recovery over $65 \%$ (by DSA-3) at a $\mathrm{pH}$ of 13.5.[12] In the same work, it was also reported that DSA-1 with two Me-groups has its maximum at $\mathrm{pH}$ 12.5 and shows only $2 \%$ extraction at $\mathrm{pH} 13.5$. These results indicate that the structure of sulfonamide extractants could be potentially fine-tuned for maximum extraction and recovery of actinides at high pHs as well as at HLW conditions. [12] 
These results inspired us to develop additional sulfonamide ligands for An(III) and Ln(III) extraction. In this paper, three types of sulfonamide ligands, a monosulfonamide (MSA-2), a disulfonamide (DSA-7), and two trisulfonamides (SA3-67 and SA3-82) were synthesized, and their Sm(III) extraction behavior from alkaline environments ( $\mathrm{pH}$ 10-14) was studied in detail. In addition, UV-Vis titrations were performed to investigate the coordination stoichiometry of DSA-7 with Sm(III).

\section{LigAND SYNTHESIS}

\subsection{Materials and Methods}

Commercial reagents and solvents were purchased from Fisher Scientific or Sigma Aldrich and were used without further purification. Sulfonamide ligands were synthesized by modification of reported procedures. $[13,14]{ }^{1} \mathrm{H}-\mathrm{NMR}$ spectra were recorded on a $600 \mathrm{MHz}$ Bruker or a $400 \mathrm{MHz}$ Bruker NMR spectrometer and were referenced to the residual solvent resonances. All ${ }^{1} \mathrm{H}-\mathrm{NMR}$ chemical shifts are recorded in ppm. FT-IR spectra were recorded on a Cary 600 series FT-IR spectrometer.

\subsection{Monosulfonamides}<smiles>CC(C)c1cc(C(C)C)c(S(=O)(=O)Nc2cc([N+](=O)[O-])ccc2O)c(C(C)C)c1</smiles>

Figure 2. Structure of MSA-2

N-(2-Hydroxy-5-nitrophenyl)-2,4,6-triisopr opylbenzene sulfonamide (MSA-2): $3.00 \mathrm{~g}$ (20 mmol) of 2-amino-4-nitrophenol was dissolved in DCM, $4.72 \mathrm{~mL}$ of pyridine was added and left to stir in an ice bath for 10 minutes. To a stirring solution, $7.00 \mathrm{~g}$ (23 mmol) of 1,3,5-triisopropylbenzenesulfonyl chloride was dissolved in DCM and added dropwise. After addition the reaction mixture was stirred at room temperature for 18 hours and monitored by TLC. When judged to be complete, work up was performed by adding excess cold water and extracting the organic phase. This was followed by washing with $1 \mathrm{M} \mathrm{HCL}, 1 \mathrm{M}$ Brine and DI water. The combined organic phases were collected and dried with $\mathrm{Na}_{2} \mathrm{SO}_{4}$, the crude product was purified using column chromatography and dried under vacuum, providing a white solid. Yield $2.10 \mathrm{~g}$, 26\%;. ${ }^{1} \mathrm{H}-\mathrm{NMR}\left(600 \mathrm{MHz}, \mathrm{CDCl}_{3}\right): \delta 8.01(\mathrm{dd}, 1 \mathrm{H}), 7.54$ $(\mathrm{d}, 1 \mathrm{H}), 7.43(\mathrm{~s}, 1 \mathrm{H}), 7.18(\mathrm{~s}, 2 \mathrm{H}), 7.04(\mathrm{~d}, 1 \mathrm{H}), 6.46(\mathrm{~s}$, $1 \mathrm{H}), 3.92(\mathrm{~m}, 2 \mathrm{H}), 2.90(\mathrm{~m}, 1 \mathrm{H}), 1.25(\mathrm{~d}, 6 \mathrm{H}), 1.19(\mathrm{~d}$, 12). ${ }^{13} \mathrm{C}$ NMR (101 MHz, $\mathrm{CDCl}_{3}$ ): $\delta 155.96$ (s), $\delta 154.44$ (s), $\delta 150.91$ (s), $\delta 141.04$ (s), $\delta 130.36$ (s), $\delta 124.36$ (s), $\delta 123.61(\mathrm{~s}), \delta 123.55(\mathrm{~s}), \delta 120.26(\mathrm{~s}), \delta 116.39(\mathrm{~s}), \delta 34.22$ (s), $\delta 30.21(\mathrm{~s}), \delta 24.71(\mathrm{~s}), \delta 23.44(\mathrm{~s}) . \mathrm{FT}-\mathrm{IR}\left(\mathrm{cm}^{-1} ;\right.$ ATR) 3269 (m); 2959 (w); $2867(\mathrm{w}) ; 1598(\mathrm{~m}) ; 1524$ (s) 1503 174 (m); $1452(\mathrm{w}) ; 1425(\mathrm{w}) ; 1403(\mathrm{w}) ; 1340(\mathrm{~s})(\mathrm{w}) ; 1320(\mathrm{~s})$ $1303(\mathrm{~m}) ; 1260(\mathrm{~m}) ; 1228(\mathrm{~m}) ; 1147(\mathrm{~s}) ; 1078(\mathrm{~m}) ; 1036$ (w); $956(\mathrm{~m}) ; 912(\mathrm{~m}) ; 881(\mathrm{~m}) ; 829(\mathrm{~m}) ; 748(\mathrm{~m}) ; 729$ (w); 666 (s); 638 (s). Elemental Analysis for MSA 2 C21H28N2O5S - Calcd: C, 59.98; H, 6.71; N, 6.66. Found: C, 59.93; H, 6.72; N, 6.67.

\subsection{Disulfonamides}

$N, N^{\prime}$-Bis-(2,4,6-triisopropylbenzene)-1,2-be nzenedisulfonamide (DSA-7): $2.70 \mathrm{~g}(27.5 \mathrm{mmol})$ of 1,2-phenylenediamine was dissolved in DCM, $4.95 \mathrm{~mL}$ of pyridine was added and left to stir in an ice bath for 10 minutes. $16.67 \mathrm{~g}(55 \mathrm{mmol})$ of 1,3,5-triisopropylbenzenesulfonyl chloride was dissolved in DCM and added dropwise to the stirring solution. After addition, the reaction was stirred at room temperature for 18 hours and monitored with TLC. When judged to be complete, workup was performed by adding excess cold water and extracting the organic phase. Then, the product was followed by washing with $1 \mathrm{M}$ HCL, $1 \mathrm{M}$ Brine, and DI water. The combined organic phases were collected and dried with $\mathrm{Na}_{2} \mathrm{SO}_{4}$, and the solvent was removed in vacuo. Addition of hot ethanol and gradual cooling with subsequent recrystallization from DCM/hexane gave a white precipitate. Yield: $8.28 \mathrm{~g}, 47 \% .{ }^{1} \mathrm{H}-\mathrm{NMR}$ (400MHz, $\left.\mathrm{CDCl}_{3}\right): \delta 9.33(\mathrm{~s}, 2 \mathrm{H}), \delta 7.26(\mathrm{~s}, 4 \mathrm{H}), \delta 7.13(\mathrm{~d}$, $2 \mathrm{H}), \delta 7.00(\mathrm{~d}, 2 \mathrm{H}), \delta 3.86(\mathrm{~m}, 4 \mathrm{H}), \delta 2.95(\mathrm{~m}, 2 \mathrm{H})$, $\delta 1.24(\mathrm{~m}, 12 \mathrm{H}), \delta 1.13(\mathrm{~m}, 24 \mathrm{H}) .{ }^{13} \mathrm{C}$ NMR $(101 \mathrm{MHz}$, $\mathrm{CDCl}_{3}$ ): $\delta 154.61$ (s), $\delta 153.37$ (s), $\delta 150.82$ (s), $\delta 146.49$ (d), $\delta 142.39$ (s), $\delta 132.10$ (d), $\delta 127.53$ (d), $\delta 124.54$ (s), $\delta 124.97$ (s), $\delta 117.16$ (s), $\delta 98.08$ (s), $\delta 34.12$ (d), $\delta 32.44$ (d), $\delta 30.12$ (s), $\delta 28.95$ (s), $\delta 24.77$ (s), $\delta 24.13$ (s), 824.01 (d), $\delta 23.54$ (s), $\delta 23.32$ (s). FT-IR ( $\mathrm{cm}^{-1}$, ATR) 3251 (m); 2960 (w); 2929 (w); 2869 (w); $1600(\mathrm{w}) ; 1567$ (w); 1497 $(\mathrm{w}) ; 1460(\mathrm{w}) ; 1427(\mathrm{w}) ; 1399(\mathrm{w}) ; 1324(\mathrm{~m}) ; 1273(\mathrm{w})$; $1256(\mathrm{w}) ; 1153(\mathrm{~s}) ; 1106(\mathrm{~m}) ; 1037(\mathrm{w}) ; 915(\mathrm{w}) ; 884(\mathrm{w})$; $803(\mathrm{~m}) ; 752(\mathrm{w}) ; 736(\mathrm{w}) ; 667(\mathrm{~s})$.

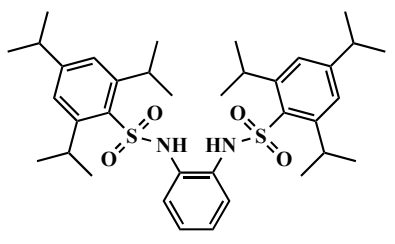

Figure 3. Structure of DSA-7

\subsection{Trisulfonamides}

$N, \quad N^{\prime}, \quad N^{\prime \prime}$-(nitrilotris(ethane-2,1-diyl)) tris(4-methylbenzenesulfonamide), (SA3-67): A THF solution containing dry triethylamine $(7.47 \mathrm{~mL}$, $53.6 \mathrm{mmol}$ ) and $p$-toluenesulfonyl chloride $(8.17 \mathrm{~g}$, $42.8 \mathrm{mmol}$ ) was purged with nitrogen. To the stirring solution, tris(2-aminoethyl)amine (2.00 $\mathrm{mL}, \quad 13.4$ mmol) was added slowly. The solution was left to stir for 24 hours at room temperature. Saturated ammonium chloride solution was added, and the product was extracted into dichloromethane. The combined organic phases were washed with $1 \mathrm{M} \mathrm{NaCl}$ and dried using $\mathrm{Na}_{2} \mathrm{SO}_{4}$. The excess solvents were removed under reduced pressure and the crude product was recrystallized using hexanes and dried 
under vacuum providing a white solid. Yield: $6.65 \mathrm{~g}$, 81.6\%. ${ }^{1} \mathrm{H}$ NMR (400 MHz, $\left.\mathrm{CDCl}_{3}\right): \delta 7.79(\mathrm{~d}, 6 \mathrm{H})$, $\delta 7.29(\mathrm{~d}, 6 \mathrm{H}), \delta 6.01(\mathrm{t}, 3 \mathrm{H}), \delta 2.92(\mathrm{q}, 6 \mathrm{H}), \delta 2.49(\mathrm{t}$, $6 \mathrm{H},), \delta 2.41(\mathrm{~s}, 9 \mathrm{H}),{ }^{13} \mathrm{C} \mathrm{NMR}\left(101 \mathrm{MHz}, \mathrm{CDCl}_{3}\right)$ :

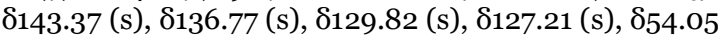
$(\mathrm{s}), 840.74(\mathrm{~s}), \delta 21.54(\mathrm{~s})$. FT-IR $\left(\mathrm{cm}^{-1}\right): 3517(\mathrm{w}), 3289$ (m), $2968(\mathrm{w}), 2857(\mathrm{w}), 1653(\mathrm{w}), 1596(\mathrm{w}), 1493(\mathrm{w})$, 1451 (m), $1414(\mathrm{~m}), 1318$ (s), 1288 (m), 1153 (vs), 1120 $(\mathrm{m}), 1090(\mathrm{~s}), 1044(\mathrm{~m}), 950(\mathrm{~m}), 915(\mathrm{~m}), 852(\mathrm{~m}), 814$ (s), $730(\mathrm{~m})$.

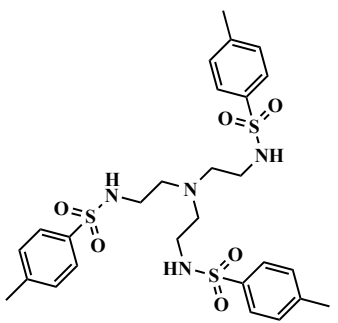

Figure 4. Structure of $\mathbf{S A 3 - 6 7}$

$N, N^{\prime}, N^{\prime \prime}$-(nitrilotris(ethane-2,1-diyl))tris(4-( tert-butyl)benzenesulfonamide) (SA3-82): A THF solution containing dry triethylamine $(7.47 \mathrm{~mL}$, $53.6 \mathrm{mmol}$ ) and 4-tert-butylbenzenesulfonyl chloride ( $9.98 \mathrm{~g}, 42.88 \mathrm{mmol}$ ) was purged with nitrogen. To this stirring solution, tris(2-aminoethyl)amine $(2.00 \mathrm{~mL}$, $13.4 \mathrm{mmol}$ ) was added slowly. The solution was left to stir for 24 hours at room temperature. Saturated ammonium chloride solution was added, and the product's extraction into the organic phase was done using dichloromethane. The combined organic phase was washed with brine and dried using $\mathrm{Na}_{2} \mathrm{SO}_{4}$. The excess solvents were removed under reduced pressure and the product was recrystallized using hexanes and dried under vacuum to give a white solid. Yield: $8.11 \mathrm{~g}$, 82.4\%. ${ }^{1} \mathrm{H}$ NMR (400 MHz, $\mathrm{CDCl}_{3}$ ): $87.83(\mathrm{~d}, 6 \mathrm{H})$, $87.50(\mathrm{~d}, 6 \mathrm{H}), \delta 6.02(\mathrm{t}, 3 \mathrm{H}), \delta 2.94(\mathrm{q}, 6 \mathrm{H}), 82.50(\mathrm{t}$, $6 \mathrm{H}), 81.30(\mathrm{~s}, 27 \mathrm{H}),{ }^{13} \mathrm{C}$ NMR $\left(101 \mathrm{MHz}, \mathrm{CDCl}_{3}\right)$ : $\delta 156.25$ (s), $\delta 136.99(\mathrm{~s}), \delta 126.98(\mathrm{~s}), \delta 126.18(\mathrm{~s}), \delta 54.39$ $(\mathrm{s}), \delta 40.95(\mathrm{~s}), \delta 35.12(\mathrm{~s}), \delta 31.11(\mathrm{~s})$. FT-IR $(\mathrm{cm}-1)$ : 3304 (s), 3259 (m), 2957 (m), $2867(\mathrm{w}), 2815$ (w), 1595 $(\mathrm{w}), 1460(\mathrm{w}), 1398(\mathrm{~m}), 1322(\mathrm{~s}), 1292(\mathrm{~m}), 1270(\mathrm{w})$, 1198 (w), 1157 (vs), 1112 (s), 1087 (s), 1049 (m), 1015 (w), $944(\mathrm{~m}), 924(\mathrm{w}), 894(\mathrm{w}), 837(\mathrm{~m}), 812(\mathrm{w}), 754$ $(\mathrm{m}), 664$ (m). Elemental Analysis for SA3-82 $\mathrm{C}_{3} 6 \mathrm{H}_{54} \mathrm{~N}_{4} \mathrm{O}_{6 \mathrm{~S}}$ - Calcd: C, 58.83; H, 7.41; N, 7.62. Found: C, 58.83; H, 7.40; N, 7.62.

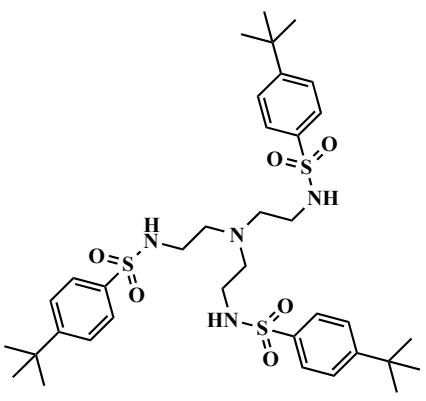

Figure 5. Structure of $\mathbf{S A 3 - 8 2}$
3. EXTRACTION STUDIES WITH SM(III)

\subsection{General methodology}

pH-Dependent extraction and stripping experiments: The extraction experiments were carried out in $15 \mathrm{~mL}$ glass tubes. The organic phases were solutions of the ligand in DCM. Extraction experiments were carried out both in the presence and absence of triethylamine. The aqueous phase was $\mathrm{Sm}\left(\mathrm{NO}_{3}\right)_{3} \cdot 6 \mathrm{H}_{2} \mathrm{O}$ in sodium hydroxide at different $\mathrm{pH}$ values $(\mathrm{pH}$ : 10.0 - 14.0). The organic and aqueous phases were mixed in stoppered glass tubes and rotated on a wheel at room temperature. After 5 min' centrifugation and separation, the Sm concentrations in the aqueous phase were determined by the Arsenazo III spectrophotometric method.[15] The stripping experiments were processed in $15 \mathrm{~mL}$ glass tubes. The organic phases resulting from extraction were stripped with $0.1 \mathrm{M} \mathrm{HNO}_{3}$. All aqueous phases were thoroughly filtered before analysis.

UV-Vis spectrophotometric determination of $\operatorname{Sm}$ (III) $(\lambda=652 \mathrm{~nm})$ : The Arsenazo III method for quantification of Sm was used in a similar fashion as reported by Savvin.[15] Sm(III) standards were purchased from Fisher Scientific and were used without further purification. $0.1 \mathrm{~mL}$ of aqueous phases after extraction and stripping experiments were obtained and mixed with $1 \mathrm{~mL}$ of $1 \%$ ascorbic acid, $1 \mathrm{~mL}$ of $0.2 \mathrm{M}$ formate buffer ( $\mathrm{pH} 3.0$ ), and $2 \mathrm{~mL}$ of $0.05 \%$ Arsenazo III solution. Then, $\mathrm{HNO}_{3}$ was used to adjust the $\mathrm{pH}$ value to 2.6 , and DI water was used to dilute the solution to $25 \mathrm{~mL}$. Sm(III) calibration standards were used to construct calibration curves. Blank samples with Arsenazo III and the buffer without Sm(III) were used as the background. Control samples after contact with organic phases that contained no ligand, showed no Sm(III) recovery, indicating that ligands are necessary components for extraction. The solutions were analyzed, and the extraction efficiency was calculated following the formula below. Since some precipitation was observed during extraction, the concentrations from the aqueous phases after stripping with $0.1 \mathrm{M} \mathrm{HNO}_{3}\left(\left[\mathrm{Sm}^{3+}\right]_{\text {(observed) }}\right)$ were applied into the formula below, rather than the concentrations of leftover Sm in the initial aqueous phases:

$$
E \%=\frac{\left[\mathrm{Sm}^{3+}\right]_{(\text {initial })}-\left[\mathrm{Sm}^{3+}\right]_{(\text {observed })}}{\left[\mathrm{Sm}^{3+}\right]_{(\text {initial })}}
$$

\subsection{Extraction studies of Sm(III) with monosulfonamide $\mathbf{M S A - 2}$}

The alkaline aqueous solutions of Sm(III) $\left(2.0 \times 10^{-3}\right.$ M) were prepared in aqueous $\mathrm{NaOH}$ with $\mathrm{pH}$ ranging from 10.0 - 14.0 and were mixed with $6.0 \mathrm{~mL}$ of MSA-2 $\left(3.0 \times 10^{-2} \mathrm{M}\right)$ in DCM. Triethylamine was used as an organic base in the control experiments. Both phases were then brought into extended contact in a rotating wheel (6o rpm; $20 \mathrm{~h})$. For stripping, both phases were centrifuged for 5 minutes to ensure proper separation. Then the organic phases were collected and filtered. $0.1 \mathrm{M} \mathrm{HNO}_{3}$ was added to the organic phase after extraction. Both phases were again rotated on a wheel ( $55 \mathrm{rpm} ; 18 \mathrm{~h})$. 
It was initially observed that in the presence of triethylamine, Sm(III) extraction was favored only at $\mathrm{pH}$ of moderate alkalinity and was below 50\%. The control experiments were performed without the inclusion of triethylamine. Without organic base however, significantly improved extraction was observed at $\mathrm{pH}$ as high as 12.5 with a maximum of $69 \%$ at $\mathrm{pH}$ 12.0 (Figure 6). However, both in the presence and absence of organic base, no Sm(III) was recovered for $\mathrm{pH}$ above 12.5, which could be attributed to heavy precipitation during the extraction process, as also seen with naked eye for high pHs. In addition, partition of this ligand to the aqueous phase in alkaline solutions is a concern due to the presence of nitro substituents, which strongly favor its hydrophilic deprotonated form at higher $\mathrm{pH}$ values.

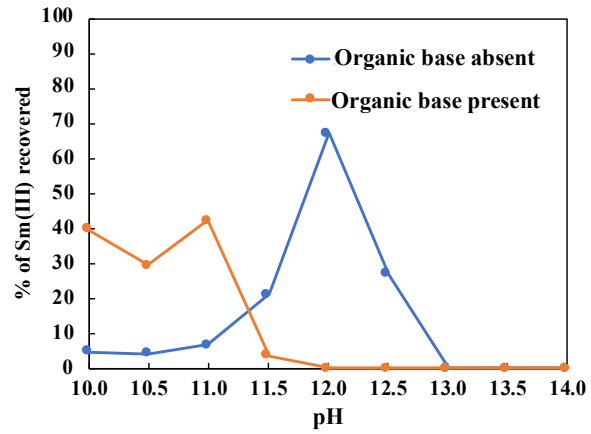

Figure 6. Extraction of Sm (III) $\left(2.0 \times 10^{-3} \mathrm{M}\right)$ with MSA-2 $\left(3.0 \times 10^{-2} \mathrm{M}\right)$ in the presence or absence of an organic base (triethylamine, $7.5 \times 10^{-2} \mathrm{M}$ ).

\subsection{Extraction studies of Sm(III) with} Disulfonamide DSA-7

Alkaline aqueous solutions of Sm(III) $\left(2.0 \times 10^{-3} \mathrm{M}\right)$ were prepared in $\mathrm{NaOH}$ with $\mathrm{pH}$ ranging from $10.0-$ 14.0, and were mixed with DSA-7 $\left(2.0 \times 10^{-2} \mathrm{M}\right)$ in dichloromethane. Both phases were then brought into extended contact in a rotating wheel $(55 \mathrm{rpm} ; 20 \mathrm{~h})$. For stripping, both phases were centrifuged for 5 minutes to ensure proper separation. Then the organic phases were collected and filtered. 0.1 $\mathrm{M} \mathrm{HNO}_{3}$ was used for stripping of the organic phases. Both phases were again rotated on a wheel $(55 \mathrm{rpm} ; 18 \mathrm{~h})$.

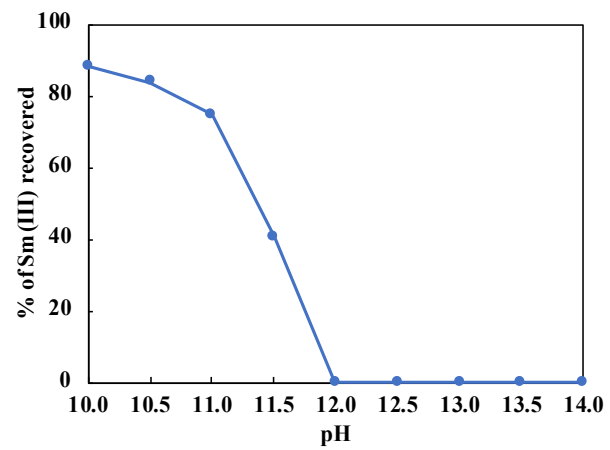

Figure 7. Extraction of Sm (III) $\left(2.0 \times 10^{-3} \mathrm{M}\right)$ with DSA-7 $\left(2.0 \times 10^{-2} \mathrm{M}\right)$ in the presence of an organic base (triethylamine, $4.0 \times 10^{-2} \mathrm{M}$ )
As shown in Figure 7, DSA-7 demonstrates similar extraction behavior with MSA-2, with high extraction ability at moderately alkaline $\mathrm{pH}$. Significant precipitation was observed during extraction for higher $\mathrm{pH}$ ranges, which hinders recovery of $\mathrm{Sm}(\mathrm{III})$ for $\mathrm{pH}>$ 12.0.

\subsection{Extraction studies of Sm(III) with \\ Trisulfonamide $\mathbf{S A 3 - 8 2}$}

Alkaline aqueous phases containing Sm(III) $(2.0 \times$ $10^{-3} \mathrm{M}$ ) were prepared in $\mathrm{NaOH}$ with $\mathrm{pH}$ ranging from $10.0-14.0$ and were contacted with $6 \mathrm{~mL}$ of solutions of SA3-82 $\left(3.0 \times 10^{-2} \mathrm{M}\right)$ in dichloromethane. Both phases were then brought into extended contact in a rotating wheel $(70 \mathrm{rpm} ; 20 \mathrm{~h})$. After contact both phases were centrifuged for 5 minutes to ensure proper separation. Then the aqueous phases were collected and the concentrations were determined by the Arsenazo-III UV-Vis spectrophotometric method method. [15]

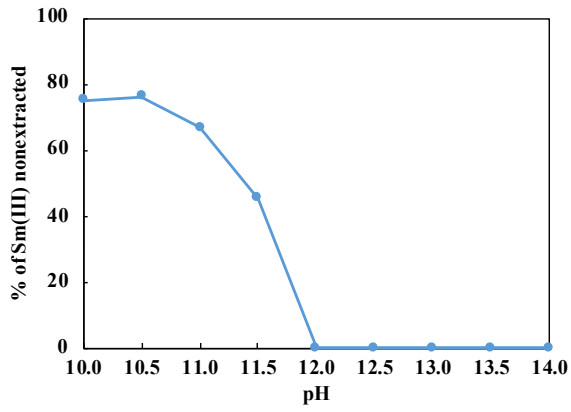

Figure $8 . \mathrm{Sm}$ (III) $\left(2.0 \times 10^{-3} \mathrm{M}\right)$ left after extraction by SA3-82 $\left(3.0 \times 10^{-2} \mathrm{M}\right)$ in the presence of an organic base (triethylamine, $7.5 \times 10^{-2} \mathrm{M}$ ).

As shown in Figure 8, SA3-82 demonstrates some $\mathrm{Sm}$ (III) extraction in moderately alkaline $\mathrm{pHs}, \mathrm{pH}$ 10.0 - 11.5). No extraction was observed for $\mathrm{pH}>12.0$. For $\mathrm{pH}>12.0$, there is extensive precipitation observed with the naked eye, which is typical for lanthanides forming insoluble hydroxides. It should be noted that all aqueous phases were thoroughly filtered before analysis.

\section{UV-VIS TITRATION STUDIES WITH SM(III)}

To determine the complexation stoichiometry of $\mathrm{Sm}$ (III) with these ligands, UV-Vis titration and H-NMR studies were carried out with varying Sm(III) concentrations. UV-Visible spectra were recorded on a CARY 100 Bio UV-Visible spectrophotometer.

The UV-Vis titration of DSA-7 with $\mathrm{Sm}\left(\mathrm{NO}_{3}\right)_{3} \cdot 6 \mathrm{H}_{2} \mathrm{O}$ in $\mathrm{CH}_{3} \mathrm{CN}$ in the presence of $\mathrm{NaOH}$ is shown in Figure 9. The concentrations of both DSA-7 and $\mathrm{NaOH}$ were kept constant, while the $\mathrm{Sm}\left(\mathrm{NO}_{3}\right)_{3} \cdot 6 \mathrm{H} 2 \mathrm{O}$ was added. After 2 hours of equilibration for each sample, data were collected within the range of 200-400 $\mathrm{nm}$. The decrease of the ligand absorption at $267 \mathrm{~nm}$ together with the increase in absorbance at $244 \mathrm{~nm}$ and the isosbestic point 
formed at $250 \mathrm{~nm}$ suggest complexation. The increase of the high energy absorption band (209 $\mathrm{nm}$ ) is mainly due to the increasing concentration of $\mathrm{Sm}^{3+}$. The absorbance values at $300 \mathrm{~nm}$ were plotted and fitted into the 1:1 binding isotherm. Nonlinear regression analysis of triplicate experiments gave a binding constant for the $1: 1 \mathrm{Sm}^{3+} / \mathbf{D S A}-7$ formation of $7.1 \times 10^{7}$ $\mathrm{M}^{-1}$. The satisfactory fits of triplicate experiments suggest $1: 1 \mathrm{M} / \mathrm{L}$ complexation in solution under the titration conditions.

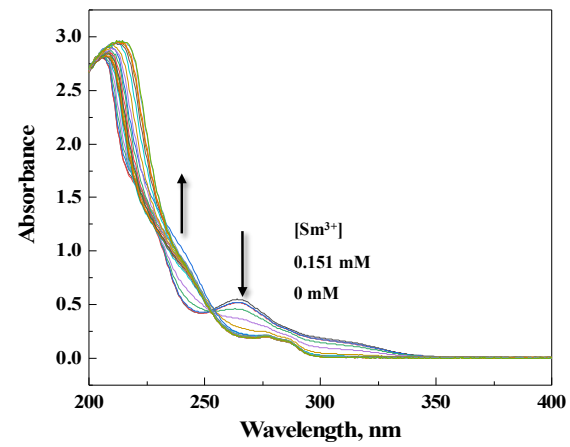

Figure 9. UV-Vis titration of DSA-7 $\left(4.0 \times 10^{-5} \mathrm{M}\right)$ and $\mathrm{NaOH}\left(8.0 \times 10^{-5} \mathrm{M}\right)$ with $\mathrm{Sm}(\mathrm{III})\left(8.0 \times 10^{-4} \mathrm{M}\right)$ in $\mathrm{CH}_{3} \mathrm{CN}$.

\section{CONCLUSION}

Three types of sulfonamide ligands, monosulfonamide (MSA-2), disulfonamide (DSA-7), and trisulfonamide (SA3-67 and SA3-83), were synthesized, and their Sm(III) extraction from alkaline solutions ( $\mathrm{pH}$ 10-14) was studied in detail. The results suggest that these ligands exhibited good extraction in moderately alkaline conditions ( $\mathrm{pH}$ 10-11.5) when triethylamine was added as an organic base. However, due to heavy precipitation at higher $\mathrm{pH}$ range, no extraction was observed in $\mathrm{pH}$ 12-14. MSA-2 showed the most promise, as up to $70 \%$ of extraction in $\mathrm{pH} 12.0$ was observed in the absence of an organic base. UV-Vis titration of DSA-7 with Sm(III) is indicative of 1:1 M:L complexation in solution. These results together suggest that sulfonamide ligands have promise for alkaline HLW extraction treatment for actinides at the Hanford and Savannah River Sites.

Acknowledgements: This work was supported by the U.S. Department of Energy Minority Serving Institution Partnership Program (MSIPP) managed by the Savannah River National Laboratory under SRNS contract BOA No. 541 TOA No. OOOO4O3071 to FIU. MLMB was supported by a U.S. Nuclear Regulatory Commission fellowship (Grant No: NRC-31310018Moo12, PI: Kavallieratos).

\section{REFERENCES}

1. P. V. Bonnesen, L. H. Delmau, B. A. Moyer, R. A. Leonard, "A Robust Alkaline-Side CSEX Solvent Suitable for Removing Cesium from Savannah River High Level Waste," Solvent Extr. Ion Exch., vol. 18, pp. 1079-1107, May 2000. https://doi.org/10.1080/07366290008934723
2. B. D. Roach et al., "Radiolytic Treatment of the NextGeneration Caustic-Side Solvent Extraction (NGS) Solvent and its Effect on the NGS Process," Solvent Extraction and Ion Exchange, vol. 33, no.2, pp. 134-151, Dec. 2014. https://doi.org/10.1080/07366299.2014.952531

3. D. T. Hobbs, T. B. Peters, K. M. L. Taylor-Pashow, S. D. Fink, "Development of an Improved Titanate-Based Sorbent for Strontium and Actinide Separations under Strongly Alkaline Conditions," Seperation Science and Technology, vol. 46, No. 1, pp. 119-129, Feb. 2010 https://doi.org/10.1080/01496395.2010.492772

4. G. R. Choppin, "Lanthanide complexation in aqueous solutions," Journal of Less Common Metals, vol. 100, pp. 141-151, Jul. 1984. https://doi.org/10.1016/0022-5088(84)90060-2

5. Z. K. Karalova, T. I. Bukina, E. A. Devirts, B. F. Agaev, B. F. Myasoedov, "Solvent extraction of americium and europium from alkaline and carbonate solutions by 2-hydroxy-5-alkylbenzyl dilthanolamine," Radiokhimiya, vol. 29, no. 6, pp. 767-772, Aug. 1988. https://www.osti.gov/etdeweb/biblio/6960906

6. I. V. Smirnov, E. S. Stepanova, A. B. Drapailo, V. I. Kalchenko, "Extraction of Americium and Europium with Functionalized Calixarenes from Alkaline Solutions," Radiochemistry, vol. 58, pp. 42-51, Feb. 2016. https://doi.org/10.1134/S1066362216010070

7. J. R. Dozol et al., "A solution, for cesium removal from high-salinity acidic or alkaline liquid waste: the crown calix [4] arenes," Separation Science and Technology, vol. 34, pp. 877-909, May 2007 https://doi.org/10.1080/01496399908951072

8. E. V. Kuzovkina, E. A. Lavrinovich, A. P. Novikov, E. S. Stepanova, M. D. Karavan, I. V. Smirnov, "Kinetics of americium and europium extraction by tert-butylthiacalix [4] arene from alkaline media," Journal of Radioanalytical and Nuclear Chemistry, vol. 311, pp. 1983-1989, Jan. 2017 https://doi.org/10.1007/s10967-017-5165-6

9. Z. K. Karalova, L. M. Rodionova, B. F. Myasoedov, "Americium and europium extraction by aliquate $336 \mathrm{xOH}$ and alkylpyrocatechol from alkaline solutions in the presence of alkylphosphonic complexones," Radiokhimiya, vol. 24, no. 2, pp. 210-213, Jan. 1982 https://www.osti.gov/etdeweb/biblio/6348014

10. Z. K. Karalova, L. M. Rodionova, B. F. Myasoedov, V.S. Kuznetsova, "Possibility of element extraction separation in alkaline media. [Extraction separation of $\mathrm{Am}, \mathrm{Cm}, \mathrm{Cf}, \mathrm{Bk}$ from La, Ce, Sm, Eu, Gd, Th, Pa, U, Pu, Zr, $\mathrm{Nb}, \mathrm{Cs}, \mathrm{Ru}, \mathrm{Fe}]$," Radiokhimiya, vol. 23, no. 1, pp. 52-57, Jan. 1981 https://www.osti.gov/etdeweb/biblio/6038242

11. A. N. Morozov, E. V. Govor, V. A. Anagnostopoulos, K. Kavallieratos, A. M. Mebel, "1,3,5-Tris-(4-(iso-propyl)phenylsulfamoylmethyl)benzene as a potential Am(III) extractant: experimental and theoretical study of Sm(III) complexation and extraction and theoretical correlation with Am(III)," Molecular Physics, vol. 116, no. 19-20, pp. 2719-2727, May 2018. https://doi.org/10.1080/00268976.2018.1471228

12. E. V. Govor, A. N. Morozov, A. A. Rains, A. M. Mebel, K. Kavallieratos, "Spectroscopic and Theoretical Insights into Surprisingly Effective Sm (III) Extraction from Alkaline Aqueous Media by o-Phenylenediamine-Derived Sulfonamides," Inorg. Chem., vol. 59, no. 10, pp. 6884-6894, Apr. 2020. https://doi.org/10.1021/acs.inorgchem.oco0309

13. L. H. Amudsen, "The Benzenesulfonyl Derivatives of o-Nitroaniline and o-Phenylenediamine," J. Am. Chem. Soc., vol. 59, no.8, pp.1466-1467, Aug. 1937 https://pubs.acs.org/doi/pdf/10.1021/ja01287a016

14. R. J. Alvarado et al., "Structural Insights into the Coordination and Extraction of $\mathrm{Pb}(\mathrm{II})$ by Disulfonamide 
X. Zhang et al., Sulfonamide ligands for Sm(III) extraction from alkaline HLW, RAD Conf. Proc., vol. 4, 2020, 173-178

Ligands Derived from o-Phenylenediamine," Inorg. Chem., vol. 44, no. 22, pp. 7951-7959, Sep. 2005

https://doi.org/10.1021/ic051103r

15. S. B. Savvin, "Analytical use of arsenazo III: Determination of thorium, zirconium, uranium and rare earth elements," Talanta, vol. 8, no. 9, pp. 673-685, Sep. 1961.

https://doi.org/10.1016/0039-9140(61)80164-1 